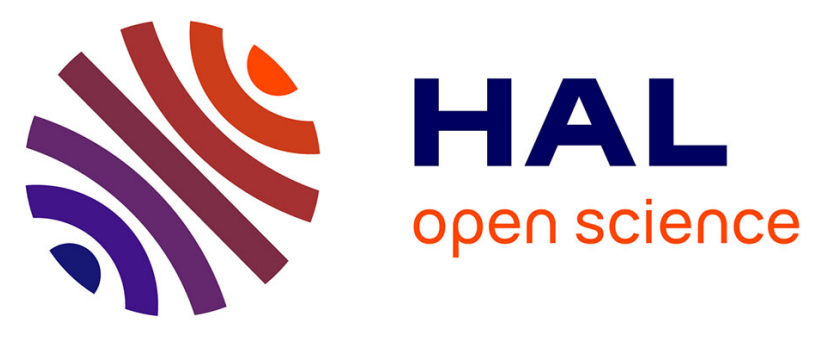

\title{
Enhanced catalytic activity and stability for the electrooxidation of formic acid on lead modified shape controlled platinum nanoparticles
}

Juan Víctor Perales-Rondón, Jose Solla-Gullón, Enrique Herrero, Carlos Sánchez-Sánchez

\section{To cite this version:}

Juan Víctor Perales-Rondón, Jose Solla-Gullón, Enrique Herrero, Carlos Sánchez-Sánchez. Enhanced catalytic activity and stability for the electrooxidation of formic acid on lead modified shape controlled platinum nanoparticles. Applied Catalysis B: Environmental, 2017, 201, pp.48-57. 10.1016/j.apcatb.2016.08.011 . hal-01415454

\section{HAL Id: hal-01415454 https://hal.sorbonne-universite.fr/hal-01415454}

Submitted on 8 Feb 2017

HAL is a multi-disciplinary open access archive for the deposit and dissemination of scientific research documents, whether they are published or not. The documents may come from teaching and research institutions in France or abroad, or from public or private research centers.
L'archive ouverte pluridisciplinaire HAL, est destinée au dépôt et à la diffusion de documents scientifiques de niveau recherche, publiés ou non, émanant des établissements d'enseignement et de recherche français ou étrangers, des laboratoires publics ou privés. 


\section{E nhanced catalytic activity and stability for the electrooxidation of formic acid on lead modified shape controlled platinum nanoparticles.}

J uan Víctor Perales-Rondón ${ }^{\mathrm{a} *}$, J ose Solla-Gullón ${ }^{\mathrm{a}}$, Enrique Herrero ${ }^{\mathrm{a}}$ and Carlos Manuel Sánchez-Sánchez ${ }^{b}$

anstituto de Electroquímica, U niversidad de Alicante Ap. 99, E-03080, Alicante, Spain.

${ }^{b}$ Sorbonne U niversités, U PM C U niv Paris 06, CNRS, Laboratoire Interfaces et Systèmes Electrochimiques, 4 place J ussieu, F-75005 Paris, France *e-mail adress: juanvictor.perales@ua.es (J uan Víctor Perales-Rondón).

\section{Abstract}

High catalytic activity for formic acid oxidation reaction (FAOR) is demonstrated in $\mathrm{Pb}$ modified shape-controlled Pt nanoparticles (N Ps). Cyclic voltammetry is used to follow the effective modification of Pt NPs by Pb. Octahedral shaped Pt NPs (having a (111) preferential surface structure) modified by $\mathrm{Pb}$ are proved the most active electrocatalyst studied towards FA OR and display a catalytic activity of c.a. $7 \mathrm{~mA} \mathrm{~cm}^{-2}$ at $0.5 \mathrm{~V}$ in 0.1 M formic acid solution. This current density represents an enhancement factor 29.5 with respect to the unmodified shaped Pt NPs and this is 2.7 and 2.3 times higher than that found on $\mathrm{Tl}_{\theta} / 100-\mathrm{Pt} \mathrm{NPS}$ and $\mathrm{Sb}_{\theta} / 111-\mathrm{Pt} \mathrm{NPS}$, respectively, some of the most active electrocatalysts based on adatoms modified Pt NPs reported so far. This outstanding activity is displayed at maximum $\mathrm{Pb}$ coverage and also confers a wide electrocatalyst stability over the entire potential range studied. FAOR is also studied using scanning electrochemical microscopy (SECM) by the micropipette delivery/substrate collection (M D/SC) working mode as a preliminary rapid test to identify active electrocatalysts. In particular, the remarkable activity enhancement exhibited by a Pt ultramicroelectrode (100 $\mu \mathrm{m}$ diameter) modified by $\mathrm{Pb}$ is rapidly imaged by SECM providing preliminary 
catalyst performance information. Thus, this technique emerges as a suitable and fast method to test, and in some cases quantify, catalyst activity for reactions of interest in fuel cell applications.

Keywords: shape-controlled Pt nanoparticles; Pb adsorption; Pb modified electrodes; formic acid oxidation; SECM .

\section{Highlights}

- Lead modified 111-Pt NPs display one of the highest current density values reported for FAOR at $0.5 \mathrm{~V}$ in $0.1 \mathrm{M} \mathrm{HCOOH}$ solution.

- Lead adatom presents a combined third body and bifunctional catalytic effect as modifier on Pt NPs.

- High catal yst stability is displayed at maximum lead coverage.

- SECM emerges as a suitable and fast tool to perform preliminary tests of electrocatalytic activity. 


\section{Introduction}

Formic acid oxidation reaction (FAOR) represents a very important reaction in electrocatalysis, since it can be used as a model in fundamental studies for other small organic molecules (SOMs) such as methanol or ethanol [1]. Moreover, formic acid has been proposed as a fuel for direct liquid fuel cells (DLFCs), which can be used as small power supply $[2,3]$ in electronic devices, since FAOR presents fast oxidation kinetics, safety in the manipulation and less fuel crossover through the ionic exchange membrane than other fuels such as methanol [4]. In a direct formic acid fuel cell (DFAFC) [5], the thermodynamic cell potential is $1.428 \mathrm{~V}$, which makes it more interesting than hydrogen fuel cells from an available energy point of view. Nevertheless, the overpotential for the FAOR at present needs to be improved in order to reach commercial applications.

Pt is one of the most studied metals in electrocatalysis [1]. In particular, FAOR on Pt electrodes has been widely studied over the last decades due to the high activity of this metal for the oxidation of different SOMs. Since FAOR has probably the simplest oxidation mechanism among all different SOMs, a deep understanding of the FAOR mechanism on Pt should be very useful for other important electrocatalytic oxidation reactions. It is well accepted that FAOR on Pt electrodes follows two different reaction pathways [6-8]. One of then, the socalled indirect via, involves the formation of $\mathrm{CO}$ on the electrode surface, which acts as a poison intermediate. The other pathway is known as the direct via, and implies the formation of an active intermediate, which is immediately oxidized into $\mathrm{CO}_{2}$. On the other hand, it is also well-known that FAOR is a surface sensitive reaction $[9,10]$. Studies on Pt single crystal electrodes (Pt(hkl)) have allowed a better comprehension of some of the elementary steps in FAOR, 
proving that $\mathrm{Pt}(100)$ is the most active electrode for both paths, while $\mathrm{Pt}(111)$ is least active one, in spite of the fact that the formation of $\mathrm{CO}$ is almost negligible on this electrode [11].

The modification of the surface chemical composition on the Pt(hkl) electrodes is one of the most widely employed methods to increase the catalytic activity for the FAOR. This strategy is mainly based on the incorporation of different adatoms, which can be either metals or semi-metals, on the surface of the Pt(hkl) electrodes. This epitaxial adsorption and deposition of a submonolayer of adatoms on a foreign metal substrate is usually performed either by irreversible adsorption at open circuit potential or by underpotential depostion (UPD). These two interesting methods to modify noble metals may generate surface alloys in some cases [12]. In the case of modified Pt electrodes, the UPD method [13] is based on the electrodeposition of an adatom monolayer from a solution containing the adatom dissolved as a cation at potentials significantly less negative than that for the bulk electrodepositon of the adatom [14]. The main difference between UPD and irreversible adsorption methods is the fact that irreversible adsorbed adatoms remain stable on the Pt surface in the absence of the adatom cation in solution [1, 15-19], but on the contrary, UPD adatoms are not stable on the Pt surface unless the solution contains the adatom cation in low concentration. Moreover, irreversible adsorption allows achieving adatom coverages independently of the applied potential, as far as it remains within the adatom electrochemical stability limits. In addition, this approach also avoids the problem of accuracy in the coverage quantification that appears when the UPD method is used, due to its dependency with the applied potential and solution composition. The well accepted positive effect of the presence of some adatoms 
on the electrocatalytic activity of Pt electrodes towards FA OR is visualized by an evident shift to lower potential values on the onset oxidation potential and/or by increasing current densities of the oxidation reaction. In this sense, it is proposed that adatoms may act following three main different mechanisms; i) the third body effect in which the foreign adatom modifies the reaction mechanism by steric interference, since it blocks specific adsorption sites on the Pt surface preventing CO formation [20], ii) the electronic effect [21, 22], where the modification of the Pt electronic structure due to the presence of foreign adatoms enhances the activity of the surface and iii) the bi-functional effect [23], in which the adatom and the Pt surface sites have distinct roles in the oxidation mechanism [24].

Over the last decades, adatoms such as bismuth (Bi) $[25,26]$, arsenic (A s) [27], antimony (Sb) [28], palladium (Pd) [29] and lead (Pb) [19, 30, 31] adsorbed on $\mathrm{Pt}(\mathrm{hkl})$ electrodes has been studied, showing an important improvement in the FAOR activity, by following at least one of the proposed mechanisms mentioned above. Nowadays, the next challenge is to transfer all that knowledge from single crystal electrodes to nanoparticles (NPs) with a preferential surface structure. In this sense, the role of some adatoms such as $\mathrm{Bi}$ [32], Sb [33] and $\mathrm{TI}$ [34] modifying shape-controlled Pt NPs have been already reported. Particularly, Bi adatom has shown a significant enhancement in the activity of the (111) preferential Pt N Ps towards FA OR [35], which agrees with previous studies using Bi modified Pt single crystal electrodes [36]. Some new approaches in the study of FAOR on modified Pt NPs electrode also include trimetallic systems [37] and graphene-Pt N Ps hybrid materials [38]. 
Despite the number of adatoms already studied modifying Pt NPs, there are still some of them untested. This is the case of $\mathrm{Pb}$ adatom on shape-controlled Pt NPs for FA OR, which is studied herein. However, $\mathrm{Pb}$ has been al ready used in Pt-Pb bimetallic alloys [39-41] to improve conventional spherical Pt NPs activity towards FA OR, as well as intermetallic Pb-Pt catalysts [42, 43]. The main goal of this article is to address that question in order to explore the feasibility of using $\mathrm{Pb}$ modified shape-controlled Pt NPs as catalyst for fuel cell applications. The use of conventional $\mathrm{Pb}$ or $\mathrm{PtPb} \mathrm{NPs}$ in real electrochemical filter press reactors either for electroorganic synthesis [44] or DFAFCs [45] have been already demonstrated in the literature.

Finally, the use of novel electroanalytical techniques for studying the reaction mechanism in electrocatalytic reactions provides new tools for electrocatalyst interrogation [46-50]. A mong of them, the scanning electrochemical microscopy (SECM) [51], which is based on the steady-state diffusion controlled regime provided by either an ultramicroelectrode (UME) or a micropipette, has already demonstrated its utility for studying FAOR [52-54]. However, no SECM imaging studies have been devoted to prove the activity improvement of adatoms modifying Pt electrodes in FAOR. So far, only a voltammetric study of FAOR on Bi modified Pt UME has been reported [55]. In the present work, we use SECM images to provide some additional information in the comparison of the activity for FAOR on pristine $\mathrm{Pt}$ and $\mathrm{Pb}$ modified $\mathrm{Pt}$ (PbPt).

\section{Experimental section}

\subsection{Chemicals}


1,2-dichloroethane $\quad\left(\mathrm{CH}_{2} \mathrm{Cl}-\mathrm{CH}_{2} \mathrm{Cl}, \quad \mathrm{DCE}\right)$ anhydrous $99.8 \%$, octyltriethoxysilane $97.5 \%$, lead (II) perchlorate hydrate $\mathrm{Pb}\left(\mathrm{ClO}_{4}\right)_{2} \cdot \mathrm{H}_{2} \mathrm{O}$ (A ldrich ${ }^{\circledR} 99.995 \%$ ), $\mathrm{H}_{2} \mathrm{SO}_{4}$ (M erck KGaA Suprapur ${ }^{\circledR} 96 \%$ ), $\mathrm{HCOOH}$ (M erck KGaG $98 \%$ ), polyethylene glycol dodecyl ether (B rij ${ }^{\circledR} 30$ ), n-heptane (ACROS Organics, Analysis), sodium borohydride (A Idrich ${ }^{\circledR}$ 99.99\%), sodium polyacrylate $\left(\right.$ Aldrich $\left.^{\circledR}\right), \mathrm{K}_{2} \mathrm{PtCl}_{4}\left(\mathrm{Aldrich}^{\circledR} 99.99 \%\right), \mathrm{H}_{2} \mathrm{PtCl}_{6} \cdot 6 \mathrm{H}_{2} \mathrm{O}$ (A Idrich ${ }^{\circledR}$ $37.50 \%), \mathrm{HCl}$ (A Idrich ${ }^{\circledR} 37 \%$ ), $\mathrm{NaOH}$ (M erck, Pellets for analysis). All solutions were prepared with ultrapure water $(18.2 \mathrm{M} \Omega \mathrm{cm}$, Purelab U Itra system, ElgaVivendi).

\subsection{E lectrochemical experiments}

\subsubsection{Voltammetric and chronoamperometric studies}

Cyclic voltammetry (CV) and cronoamperometry (CA) were performed using a conventional electrochemical glass cell of 3 electrodes at room temperature and a potentiostat-galvanostat A UTOLAB PGSTAT302N (M etrohm A utolab B. V.) or a potentiostat CHI 760E. The working electrode was prepared by adding $4 \mu \mathrm{L}$ of each type of Pt NPs (2 $\mu \mathrm{L}$ for 100-Pt NPs) coating a $3 \mathrm{~mm}$ diameter gold ( $\mathrm{Au}$ ) disc electrode, which is used as a N Ps support and current collector, and allowing the water solvent to be evaporated before entering the electrode in the cell. The sample volume of $4 \mu \mathrm{L}$ was selected after performing a calibration curve that proved no diffusion limitations for FAOR due to the thickness of that layer of NPs deposited on the gold disc electrode. Each Pt NPS suspension was sonicated for 2 min before being used. A gold wire was used as a counter electrode, and a reversible hydrogen electrode (RHE) within a Luggin capillary was employed as a reference electrode. All potentials used in this paper 
are referred to RHE. CV s for Pt surface area quantification were carried out in a deaerated $0.5 \mathrm{M} \mathrm{H}_{2} \mathrm{SO}_{4}$ solution. $\mathrm{CV}$ s and $\mathrm{CAs}$ for studying the electrocatalytic activity for FAOR were carried out in deaerated $0.1 \mathrm{M} \mathrm{HCOOH}$ and $0.5 \mathrm{M}$ $\mathrm{H}_{2} \mathrm{SO}_{4}$ solution. An electrochemical pre-treatment for removing the $\mathrm{CO}_{\text {ads }}$ accumulated at the electrode surface from previous FAOR experiments was performed before starting each CA. This consists in holding the electrode potential at $0.8 \mathrm{~V}$ for $5 \mathrm{~s}$. The potential window where it is possible to work avoiding structure modifications on the shape-controlled Pt NPs surface is between $0.05 \mathrm{~V}$ and $0.8 \mathrm{~V}[56,57]$.

\section{3. $\mathrm{Pb}$ modified shape controlled Pt NPs ( $\left.\mathrm{Pb}_{\theta} / \mathrm{Pt} \mathrm{NPs}\right)$}

Three types of shape-controlled Pt NPs dispersed in water with surface area to volume ratios of $0.03 \mathrm{~cm}^{2} \mu \mathrm{L}^{-1}$ for Cubic 100-Pt NPs and $0.017 \mathrm{~cm}^{2} \mu \mathrm{L}^{-1}$ for octahedral 111-Pt NPs and for quasi-spherical poly-Pt NPs were used. The chemical synthesis of those NPs was carried out as previously described in detail [58]. The Pt NPs morphology/shape was confirmed by transmission electron microscopy (TEM and HRTEM). TEM experiments were performed with a JEOL JEM-2010 microscope and a JEOL 3010 microscope working at $200 \mathrm{kV}$ and 300 $\mathrm{kV}$, respectively. The procedure to get all the TEM images is explained in detail elsewhere [59].

The average particle size of the cubic and octahedral NPs was around 9 $\mathrm{nm}$, whereas the size of the quasi-spherical NPs was around $4 \mathrm{~nm}$. B efore being modified with $\mathrm{Pb}$, the Pt NPs were electrochemically characterized and a CO adsorption-stripping experiment was performed in order to clean the Pt NPs surface, as has been previously reported $[57,58]$. In brief, this procedure consists 
in blocking the Pt NPs electrode surface by bubbling $\mathrm{CO}$ in solution for about 30 s. After this time the electrode is kept at potential $0.1 \mathrm{~V}$ for about $15 \mathrm{~min}$, while the solution is bubbled with $\mathrm{Ar}(\mathrm{g})$ in order to remove any $\mathrm{CO}$ traces in solution. Finally, the CO adsorbed on the Pt NPs electrode surface is stripped and converted into $\mathrm{CO}_{2}$ by running a $\mathrm{CV}$ at slow scan rate $\left(20 \mathrm{mV} \mathrm{s}^{-1}\right)$, which reaches a high enough positive potential ( $0.8 \mathrm{~V}$ vs RHE). Then, each type of Pt NPs was electrochemically characterized in $0.5 \mathrm{M} \mathrm{H}_{2} \mathrm{SO}_{4}$ solution before and after the irreversible adsorption of $\mathrm{Pb}$ adatoms on its surface. The Pt NPs active surface area was determined by the charge involved in the hydrogen UPD region (between $0.05 \mathrm{~V}$ and $0.50 \mathrm{~V}$ for 100 -Pt NPs; $0.05 \mathrm{~V}$ and $0.45 \mathrm{~V}$ for poly-Pt NPs, and $0.05 \mathrm{~V}$ and $0.65 \mathrm{~V}$ for 111-Pt NPs) after the subtraction of the double layer [57]. Then, $\mathrm{Pb}$ adatoms were irreversibly adsorbed on each type of Pt N Ps outside the electrochemical cell by simple immersion of Pt NPs at open circuit potential within dilute solutions of $10^{-3} \sim 10^{-5} \mathrm{M} \mathrm{Pb}\left(\mathrm{ClO}_{4}\right)_{2}$ in $0.5 \mathrm{M} \mathrm{HClO}_{4}$ and following a common procedure for the irreversible adsorption of different adatoms on Pt [60]. After this, the electrode was rinsed with ultrapure water (except for the maximum coverage case, where the electrodes were not rinsed before being immersed into the solution) and transferred to an electrochemical cell (different to the one used for Pt NPs electrochemical characterization) to perform the electrocatalytic test for $\mathrm{FAOR}$ in deaerated $0.1 \mathrm{M} \mathrm{HCOOH}$ and $0.5 \mathrm{M} \mathrm{H}_{2} \mathrm{SO}_{4}$ solution. By varying the adatom concentration in solution as well as the electrode immersion time, different $\mathrm{Pb}$ adatom coverages can be reached on the Pt NPs surface. Finally, the Pb coverage $\left(\theta_{\mathrm{Pb}}\right)$ on the Pt NPs surface was quantified by following the decrease of the charge involved in the hydrogen adsorption or 
desorption peaks present in the hydrogen UPD region of the corresponding cyclic voltammetry, according to the equation:

$$
\theta_{P b}=1-\theta_{H}=\frac{q_{H}^{0}-q_{H}^{P b}}{q_{H}^{0}}
$$

where $q_{H}^{0}$ and $q_{H}^{P b}$ are the hydrogen desorption charges for the pristine and $\mathrm{Pb}$ modified Pt electrodes respectively, calculated after the subtraction of the double layer contribution [34, 35]. However, as it was al ready described for Sb [33] and TI [34] modified Pt NPs, the characterization of $\theta_{\mathrm{Pb}}$ is not possible at high $\mathrm{Pb}$ coverage, since the decrease in the hydrogen adsorption/desorption peaks shown in the hydrogen UPD region is compensated by the appearance of a new peak associated with a surface $\mathrm{Pb}$ oxidation/reduction signal from the $\mathrm{Pb}$ adsorbed on the gold substrate electrode, preventing the quantification of high $\mathrm{Pb}$ coverages by this procedure. Thus, the maximum $\mathrm{Pb}$ coverage obtained on each type of $\mathrm{Pt}$ NPs studied here is not quantified and it is identified as $\theta_{\max }$. Then, the three types of Pb modified Pt NPs are named: i) $\mathrm{Pb}_{\theta} / 100-\mathrm{Pt} N \mathrm{Ps}$, ii) $\mathrm{Pb}_{\theta} / 111-\mathrm{Pt} \mathrm{NPs}$ and iii) $\mathrm{Pb}_{\theta} /$ poly-Pt NPs.

\subsection{Scanning E lectrochemical M icroscopy (SE C M )}

The working electrode for SECM experiments was a $100 \mu \mathrm{m}$ diameter pristine Pt UME and the same electrode after in-situ surface modification by irreversible adsorption of $\mathrm{Pb}$ (3 min immersed in a diluted $\mathrm{Pb}\left(\mathrm{ClO}_{4}\right)_{2}$ solution) (Pb-Pt). SECM images were carried out using the micropipette delivery/substrate collection (MD/SC) mode [53] of SECM using a $\mathrm{CHI} 910 \mathrm{~B}$ microscope $(\mathrm{CH}$ Instruments) and a three-electrodes configuration cell at room temperature. The micropipettes used to deliver the $\mathrm{HCOOH}$ in the vicinity of the studied electrodes 
presented an opened diameter of ca. 15-20 $\mu \mathrm{m}$ and were loaded with a mixture 50:50 (v/v) DCE:HCOOH. They were fabricated by pulling borosilicate capillaries with O.D.: $1.5 \mathrm{~mm}$, I.D.: $1.0 \mathrm{~mm}$ and length $90 \mathrm{~mm}$ using a laserbased puller P-2000 from Sutter Instrument Co. The inner walls of the micropipettes were made hydrophobic following a well-established silanization protocol $[61,62]$ by filling them with octyltriethoxylsilane overnight and finally, drying them exhaustively. For MD/SC SECM imaging [53, 63], a gold wire, 0.5 $\mathrm{mm}$ diameter, was used as counter electrode and a commercial $\mathrm{Hg} / \mathrm{Hg}_{2} \mathrm{SO}_{4}$ $\left(\mathrm{K}_{2} \mathrm{SO}_{4}\right.$ sat.) electrode within a Luggin capillary as reference, although all potential values have been referred in the article to $\mathrm{RHE}\left(\mathrm{E}_{(\mathrm{Hg} / \mathrm{Hg} 2504)}=+0.64 \mathrm{~V}\right.$ vs RHE). The electrochemical cell employed was built in Teflon with a $2 \mathrm{~mm}$ diameter aperture, where the Pt UM E perfectly fitted facing up and was held at a potential value positive enough to produce the electrochemical oxidation of $\mathrm{HCOOH}$ at the electrode surface. An electrochemical pre-treatment for removing the $\mathrm{CO}_{\text {ads }}$ accumulated at the electrode surface was performed before each SECM image. This consists in holding the electrode potential constant at $0.8 \mathrm{~V}$ for $5 \mathrm{~s}$. The micropipette was located at a constant tip-substrate distance in $Z(d=50 \mu \mathrm{m})$ facing the Pt UME and the MD/SC SECM images were obtained recording the substrate current while the micropipette was scanned on the $X-Y$ plane in an argon saturated $0.5 \mathrm{M} \mathrm{H}_{2} \mathrm{SO}_{4}$ solution. The tip scan rate was $75 \mu \mathrm{m} \mathrm{s}^{-1}$, using increments of $15 \mu \mathrm{m}$ each $0.2 \mathrm{~s}$.

\section{Results and discussion}

\subsection{FAOR activity enhancement on modified Pb-Pt electrodes by SE C M imaging.}


Figure 1 displays several SECM images for FAOR on pristine and $\mathrm{Pb}$ modified with the highest coverage $\left(\theta_{\max }\right)$ Pt electrodes, using the MD/SC mode of the SECM for imaging. In this mode, the species of interest $(\mathrm{HCOOH})$ is delivered within the solution through a micropipette by crossing the liquid-liquid interface between two immiscible phases, $D C E$ and $\mathrm{H}_{2} \mathrm{O}$, within and without the micropipette, respectively. $\mathrm{M}$ oreover, $\mathrm{HCOOH}$ delivery rate is controlled by its partition coefficient in both immiscible phases [53]. These SECM images were taken at two different potentials, namely, $0.3 \mathrm{~V}$ and $0.5 \mathrm{~V}$. B rown color in the figure corresponds to the background current, and green color means an increase in the oxidation current because of the oxidation of $\mathrm{HCOOH}$ on the electrode.

Figure 1 shows a much higher net oxidation current appearing when the micropipette scans above Pb-Pt than on Pt electrode at both studied potentials. In fact, the current collected at $0.3 \mathrm{~V}$ on Pt is so low that a dashed circle has been added into the image to mark the exact Pt electrode location. Thus, these facts clearly point out that the current collection for FAOR (difference between the maximum current at the electrode location and the background current in the SECM image at a given tip-substrate distance [64]) is significantly higher in the case of $\mathrm{Pb}$ modified Pt electrode. Table 1 summarizes the collected current for $\mathrm{Pt}$ and $\mathrm{Pb}$-Pt electrodes at both potentials exhibiting values from 1.1 to $34.8 \mathrm{nA}$. M oreover, the catalytic enhancement factor, which in this case is defined as the ratio between the collected current on $\mathrm{Pb}$-Pt electrode versus that collected on $\mathrm{Pt}$ electrode at the same potential and tip-substrate distance, is calculated and included in Table 1.

\subsection{Characterization and stability of Pb modified shape controlled Pt NPs.}


Once the FAOR activity enhancement on modified $\mathrm{Pb}$ - $\mathrm{Pt}$ electrodes has been demonstrated by preliminary rapid SECM imaging, it is necessary to transfer those results into Pt NPs in order to gain insight into the catalytic mechanism and to envisage the potential feasibility of using Pb modified Pt NPs as electrocatalysts for real DFAFCs.

Figure 2 shows some representative TEM images of the different $\mathrm{Pt}$ nanoparticles employed in this work. The results obtained are similar to those previously reported [58]. In figure 2a Pt nanoparticles with octahedral and tetrahedral shapes can be easily distinguished. These shapes would suggest the presence of a $\{111\}$ preferential orientation. On the other hand, figure $2 b$ shows Pt nanoparticles with a preferential cubic shape thus suggesting a preferential $\{100\}$ orientation. Finally, spherical Pt nanoparticles with a poly-oriented surface can be observed in figure $2 \mathrm{c}$. It is worth noting that before preparing the $\mathrm{Pb}$ modified Pt NPs, a careful verification of the current contribution provided by the substrate electrode used as a support and current collector should be conducted. In order to carry out that verification, the $\mathrm{Pb}$ surface modification (maximum coverage) of an Au disk electrode was performed. The voltammetric profiles of $\mathrm{Pb}$ modified $\mathrm{Au}$ disk (black plot) and Pb modified 111-Pt N Ps supported on A u disk electrode (red plot) are displayed in figure 3. The main feature observed in both curves corresponds to a sharp anodic peak around $0.22 \mathrm{~V}$, which is associated with $\mathrm{Pb}$ UPD/dissolution at different crystal faces of the Au substrate [65]. This is evident in figure 3a when comparing the response of 111-Pt N Ps on A u substrate (red plot) and on glassy carbon (GC) substrate (blue plot), where the main difference corresponds to the sharp peak displayed at $0.22 \mathrm{~V}$ only present in the $\mathrm{A}$ u substrate case. A broad redox signal extended from $0.3 \mathrm{~V}$ to $0.8 \mathrm{~V}$ only 
appears when the electrode contains 111-Pt NPs, suggesting Pb redox processes on the Pt surface taking place at more positive potentials than on $\mathrm{A} u[19,31,66$, 67]. Furthermore, the presence of 111-Pt N Ps in the electrode causes an important raise in the apparent double layer capacitance current. These signals are associated to the $\mathrm{Pb}$ redox processes and are only well-observed for high coverages. Finally, figure $3 \mathrm{~b}$ exhibits the response of $\mathrm{Pb}$ modified $\mathrm{Au}$ and bare $\mathrm{Au}$ electrodes for the FAOR, showing no activity enhancement when the $\mathrm{Au}$ electrode is modified by $\mathrm{Pb}$. This fact rules out any relevant effect of the $\mathrm{Au}$ substrate electrode in the electrocatalytic behavior displayed by the Pt NPs studied.

Figure 4 shows the electrochemical characterization of all three types of shape controlled Pt NPs modified with different coverage of Pb in sulfuric acid solution. The voltammetric profiles without $\mathrm{Pb}$ modification $\left(\theta_{\mathrm{Pb}}=0\right)$ agree with those reported already in the literature for shaped controlled Pt N Ps [68]. Then, for the three types of shape controlled Pt N Ps modified with different amount of $\mathrm{Pb}$, the charge associated within the hydrogen adsorption and desorption region on Pt clearly decreases when the amount of $\mathrm{Pb}$ is increased. The $\mathrm{Pb}$ coverage is estimated using equation (1). Nevertheless, the peak appeared around $0.22 \mathrm{~V}$ when the amount of $\mathrm{Pb}$ is significantly increased $\left(\theta_{\mathrm{Pb}}=\max \right)$, which is due to a redox process associated to $\mathrm{Pb}$ adsorbed on the $\mathrm{Au}$ polycrystalline surface [65, 69], prevents a proper $\mathrm{Pb}$ coverage quantification. For this reason, the maximum $\mathrm{Pb}$ coverage is not quantified $\left(\theta_{\max }\right)$.

The stability of the Pb adlayer on Pt NPs before (solid plots) and after (dash dotted plots) FAOR is shown in Figure 5 at both, high ( $\theta_{\max }$, red plots) and low coverage (black plots, $\theta_{\mathrm{pb}} / 100-\mathrm{Pt}=0.27$ and $\theta_{\mathrm{pb}} / 111-\mathrm{Pt}=0.31$ ), in sulfuric 
acid solution $0.5 \mathrm{M}$. At low $\mathrm{Pb}$ coverage, the $\mathrm{Pb}$ deposition is more unstable and the characteristic hydrogen features are clearly identified after FAOR experiment (dash dotted black plot), due to the partial dissolution of $\mathrm{Pb}$ [70]. A similar behavior is found when increasing the number of electrochemical cycles that reach $0.8 \mathrm{~V}$ as a positive cycle limit (not shown). On the contrary, at maximum $\mathrm{Pb}$ coverage, the modified electrode profile before and after $\mathrm{FAOR}$ remains stable, which may suggest the formation of a chemically stable Pb surface alloy on Pt when high coverages are reached, which avoids its rapid dissolution and confers more durability to the catalyst.

\subsection{FAOR on Pb modified shape controlled Pt NPs.}

Figure 6 presents the positive scan direction of $\mathrm{CV} s$ for all three different types of shape controlled Pt NPs at different Pb coverage, and the negative scan direction only for $\theta_{\mathrm{Pb}}=0$ and $\theta_{\mathrm{Pb}}=\max$. In particular, Figure 6a exhibits pristine and $\mathrm{Pb}$ modified poly-Pt NPs. This type of Pt NPs represents the most comparable case to the bulk Pt electrode used for SECM imaging (Figure 1). M oreover, the current density at potentials below $0.30 \mathrm{~V}$ is almost negligible in the positive potential scan in all three types of pristine Pt N Ps shown in Figure 6 (see Table 2), which is due to $\mathrm{CO}_{\text {ads }}$ poisoning effects. However, this behavior is particularly important in the pristine 100-Pt NPs (figure 6b, solid black plot), which perfectly agrees with previous Pt(hkl) studies, which demonstrated that (100) domains are the most active for the CO formation during FAOR [22]. A bove $0.3 \mathrm{~V}$, the current density on pristine Pt NPs increases slowly until $\sim 0.80$ V. In contrast, the negative potential scans (dashed black plots in Figure 6) show significantly higher current densities producing an important hysteresis in all 
three cases because the $\mathrm{CO}$ is removed from the electrode surface at $0.8 \mathrm{~V}$. Figure 6 also shows a significant increase in the oxidation current densities when $\mathrm{Pb}$ is present on the surface of all three types of Pt NPs, even at low Pb coverages $\left(\theta_{\mathrm{Pb}}\right.$ $<0.2$ ), reaching a maximum at $\sim 0.50 \mathrm{~V}$. M oreover, this activity enhancement is displayed in both positive and negative scan directions, exhibiting a very small hysteresis when $\mathrm{Pb}$ is present on the Pt NPs surface. In fact, for $\mathrm{Pb}_{\theta} /$ poly-Pt N Ps there is not hysteresis between both scans, whereas in the cases of $\mathrm{Pb}_{\theta} / 100-\mathrm{Pt}$ $\mathrm{NPs}$ and $\mathrm{Pb}_{\theta} / 111-\mathrm{Pt} \mathrm{NPs}$, this effect is somehow more visible, being always the current in the positive scan larger than in the negative one. This behavior is completely different from that observed in unmodified Pt NPs and indicates suppression of $\mathrm{CO}$ formation when $\mathrm{Pb}$ is present on the Pt NPs surface. Furthermore, there is a shift of the onset potential for the FAOR with respect to the unmodified Pt NPs towards less positive potentials $(\sim 0.15 \mathrm{~V})$ in all three cases. M ore importantly, a significant current increase is observed for $\mathrm{Pb}_{\theta} / 111-\mathrm{Pt}$ NPs and particularly at maximum $\mathrm{Pb}$ coverage $\left(6718 \mu \mathrm{A} \mathrm{cm} \mathrm{cm}^{-2}\right.$ at $\left.0.5 \mathrm{~V}\right)$.

Table 2 summarizes the density current values reached at $0.3 \mathrm{~V}$ and $0.5 \mathrm{~V}$ in the positive scan direction for each type of shape controlled Pt NP at $\theta_{\mathrm{Pb}}$ maximum. Additionally, in order to achieve a proper comparison with other adatoms al ready studied in the literature, comparable results for FAOR using Sb [33] modified Pt NPs and TI [34] modified Pt NPs are also included in Table 2. That comparison points out that $\mathrm{Sb}_{\theta} / 111-\mathrm{Pt} N \mathrm{Ps}$ and $\mathrm{TI}_{\theta} / 100-\mathrm{Pt} \mathrm{N}$ S exhibit a little bit larger current densities than any of the Pb modified Pt N Ps at $0.3 \mathrm{~V}(1.2$ and 1.1 times higher than $\mathrm{Pb}_{\theta} / 111-\mathrm{Pt} \mathrm{NPs}$, respectively). Nevertheless, the maximum current reported for FAOR on Pt N Ps modified by adatoms at higher potentials (at $0.5 \mathrm{~V}$ ) is the one exhibited by $\mathrm{Pb}_{\theta} / 111$-Pt NPs (2.7 times higher 
than on $\mathrm{TI}_{\theta} / 100$-Pt NPs and 2.3 higher than on $\mathrm{Sb}_{\theta} / 111$-Pt N Ps). In addition to this, all three types of Pb modified Pt NPs exhibit higher current densities than Sb or TI modified Pt NPs at $0.5 \mathrm{~V}$, independently of the preferential Pt surface structure. Furthermore, the modification by $\mathrm{Pb}$ provides the highest average current comparing all 3 adatoms and considering the average of all three types of $\mathrm{NPs}$ for each case, both at 0.3 and $0.5 \mathrm{~V}$, since the reaction is less sensitive to the surface structure of the NPs, which also supports the possible formation of a chemically stable Pb-Pt surface alloy [71].

Figure 7 shows the catalytic enhancement factor for FAOR as a function of applied potential calculated from the corresponding positive-sweep voltammetric profiles displayed in Figure 6 . This factor of normalization is defined as the ratio between the current densities of $\mathrm{Pb}$ modified Pt NPs at maximum $\mathrm{Pb}$ coverage and that obtained in the corresponding pristine Pt NPs. It can be seen that, despite $\mathrm{Pb}_{\theta} / 111$-Pt NPs is the most active electrode comparing absolute values of current density, the normalized activity is very similar to that of $\mathrm{Pb}_{\theta} / 100-\mathrm{Pt} \mathrm{NPs}$. However, $\mathrm{Pb}_{\theta} /$ poly-Pt NPs show a lower increase in the activity. In fact, the maximum normalized activity is reached around $0.37-0.40$ $\mathrm{V}$, and the catalytic enhancement factor is 29.5 and 28.5 for $\mathrm{Pb}_{\theta} / 111$-Pt N Ps and $\mathrm{Pb}_{\theta} / 100-\mathrm{Pt} \mathrm{NPs}$, respectively, and 18 for $\mathrm{Pb}_{\theta} /$ poly-Pt NPs. This fact could be related with a NPs size effect. Since poly-Pt NPs are significantly smaller than the others, they have a larger fraction of edge atoms on their surface, which affords a smaller catalytic enhancement factor. Thus, a Pb adatom deposited neighboring to an edge will have a lower amount of neighboring Pt surface atoms, but the increase in activity is proportional to the number of Pt-Pb ensembles created by the adatom deposition, that is, to the number of $\mathrm{Pt}$ 
neighboring the $\mathrm{Pb}$ adatom [20]. It is clear that the deposition of $\mathrm{Pb}$ close to an edge will result in an increase of activity lower than that measured when the adatom is deposited in the middle of a large domain. However, despite a lower increase, the shape of the curve in figure 7 is the same in all three cases, which indicates that the actuation mechanism is the same in all Pb modified Pt NPs. Furthermore, no difference is observed when comparing the catalytic enhancement factor at $0.3 \mathrm{~V}$ calculated from the current collected within the SECM images (13, see Table 1) and the one calculated from the positive-sweep voltammetric profiles in Figure 6a for Pb modified poly-Pt NPs (13.5, see Table 2 ), since that potential fits into the charge transfer control regime. In contrast, the same comparison at $0.5 \mathrm{~V}$, a potential at which diffusion may play a role in the kinetics, denotes a clear underestimation of the catalytic enhancement factor when it is calculated from SECM images, mainly due to the tip-substrate distance used in figure 1, which does not allow a 100\% collection efficiency.

Figures 8 and 9 show the chronoamperometric experiments for $600 \mathrm{~s}$ at 0.3 and $0.5 \mathrm{~V}$, respectively, obtained with all three types of $\mathrm{Pb}$ modified Pt NPs. Chronoamperometric experiments not only provide information about the catalytic enhancement at any specific potential, but also it can give some light about the stability of the catalytic activity vs. time. For this reason, they may be used to calculate the deactivation rate, which is defined as $\left(j_{60 s}-j_{600 s}\right) / j_{60 s}$ and it is reported in Table 3. In particular, figure 8 shows that all three types of $\mathrm{Pb}$ modified Pt NPs provide similar current density values (aprox. $400 \mu \mathrm{A} \mathrm{cm}{ }^{-2}$, see Table 3) at maximum $\mathrm{Pb}$ coverage after $600 \mathrm{~s}$, which implies that there is not a specific surface structure effect in the activity when modifying by $\mathrm{Pb}$ at this potential, as was also suggested by the voltammetric behavior. However, when 
the cronoamperometric experiment is performed at $0.5 \mathrm{~V}$ (figure 9), the $\mathrm{Pb}_{\theta} / 111$ Pt NPs at maximum Pb coverage clearly exhibits the highest current density value after $600 \mathrm{~s}\left(4190 \mu \mathrm{A} \mathrm{cm}{ }^{-2}\right.$, see Table 3), showing also a moderate deactivation rate $(15 \%$, see Table 3$)$ similar to the one already reported for $\mathrm{Sb}_{\theta} / 111$-Pt N Ps at optimum Sb coverage [33].

\subsection{FAOR mechanism discussion for $\mathrm{Pb}$ modified shaped controlled Pt NPs.}

As it is well known, $\mathrm{HCOOH}$ can yield adsorbed $\mathrm{CO}$ by a dehydration reaction [72]. This process has specific surface site requirements [20, 73], which makes the reaction susceptible of control by adding adatoms, which can act blocking some surface Pt ensemble sites and hindering in this way the CO formation. From the voltammetric profiles shown in Figure 6 it is clear that the $\mathrm{CO}$ adsorption is hindered by the presence of $\mathrm{Pb}$ on the Pt NPs surface, at low and high coverage, because of a third body effect $[26,74]$. This is more evident by the loss of the hysteresis between the positive and negative potential sweep at each case compared with the unmodified Pt N Ps.

As in the case of other electropositive adatoms such as $\mathrm{Bi}, \mathrm{Sb}$ or $\mathrm{Te}$, their presence on Pt promotes the adsorption of the formate on the adatom in a configuration which facilitates the cleavage of the $\mathrm{C}-\mathrm{H}$ bond with almost no activation energy on a neighboring Pt site, justifying a bifunctional mechanism by the $\mathrm{Pb}$ adatom. This is well documented and demonstrated in recent contributions $[26,74]$. This behavior is certain assuming only the formation of a submonolayer of adatom on the electrode surface. In parallel, the presence of $\mathrm{Pb}$ hinders the dehydration reaction of $\mathrm{HCOOH}$ [75]. Thus, the net result of both mechanism of 
action is that the formation of $\mathrm{CO}$ is almost completely inhibited and much higher oxidation currents are reached by the direct pathway.

\section{Conclusions}

Pb modified shape controlled Pt N Ps represents a highly efficient method for improving the catalytic activity for FAOR of Pt NPs by reaching catalytic enhancement factors as high as 29.5. In particular, $\mathrm{Pb}_{\theta} / 111-\mathrm{Pt} \mathrm{NPs}$ at $\theta_{\max }$ reaches 2.7 times higher current density than $\mathrm{TI}_{\theta} / 100-\mathrm{Pt} \mathrm{NPs}$ [34] and 2.3 higher than $\mathrm{Sb}_{\theta} / 111$-Pt NPs [33] at $0.5 \mathrm{~V}$ in $0.1 \mathrm{M} \mathrm{HCOOH}$ and $0.5 \mathrm{M} \mathrm{H}_{2} \mathrm{SO}_{4}$ solution, so far, two of the most active catalysts reported for FAOR under low reactant concentration conditions $(0.1 \mathrm{M})$. It should be also highlighted that all three types of $\mathrm{Pb}$ modified Pt NPs studied at maximum $\mathrm{Pb}$ coverage exhibit higher current density at $0.5 \mathrm{~V}$ than $\mathrm{TI}_{\theta} / 100-\mathrm{Pt} \mathrm{NPS}$ and $\mathrm{Sb}_{\theta} / 111-\mathrm{Pt} \mathrm{NPS}$, which could suggest the formation of a Pb surface alloy on the Pt surface at high Pb coverage and an important bifunctional effect leading the FAOR mechanism towards the direct reaction pathway and suppressing the $\mathrm{CO}$ formation by a third body effect. M oreover, at maximum $\mathrm{Pb}$ coverage, the modified electrode voltammetric profile remains stable after $F A O R$ in a wide potential range, which confers a remarkable durability to the $\mathrm{Pb}$ modified $\mathrm{Pt}$ electrodes and opens up its application in diffusion gas electrodes for fuel cells. Finally, it should be pointed out that the SECM imaging by the MD/SC mode emerges as a suitable and fast method to perform preliminary catalytic tests, and in some cases quantify, the catalyst activity for reactions of interest in fuel cell applications, such as FAOR, providing a fast method to test in advance the effect of a specific adatom adsorbed on metallic electrodes. 


\section{Acknowledgements}

This work has been financially supported by the MICINN (Spain) (projects CTQ2013-44083-P and CTQ2013-48280-C3-3-R), Generalitat Valenciana (project PROMETEOII/2014/013, FEDER) and CNRS (project Défi Instrumentation aux limites 2015).

\section{R eferences}

[1] M.T.M. Koper, Fuel Cell Catalysis: A Surface Science Approach, John Wiley \& Sons, Hoboken, New J ersey, 2009.

[2] C. Rice, R.I. Ha, R.I. M asel, P. Waszczuk, A. Wieckowski, T. Barnard, J. Power Sources 111 (2002) 83-89.

[3] N.V. Rees, R.G. Compton, J. Solid State Electrochem. 15 (2011) 2095-2100.

[4] S. Uhm, H.J. Lee, J. Lee, Phys. Chem. Chem. Phys. 11 (2009) 9326-9336.

[5] X. Y u, P.G. Pickup, J. Power Sources 182 (2008) 124-132.

[6] A . Capon, R. Parsons, J. Electroanal. Chem. 44 (1973) 1-7.

[7] A. Capon, R. Parsons, J. Electroanal. Chem. 44 (1973) 239-254.

[8] A. Capon, R. Parsons, J. Electroanal. Chem. 45 (1973) 205-231.

[9] V. Grozovski, V. Climent, E. Herrero , J.M. Feliu, Phys. Chem. Chem. Phys. 12 (2010) 8822-8831.

[10] S.G. Sun, Y.Y. Y ang, J. Electroanal. Chem. 467 (1999) 121-131.

[11] V. Climent, J.M. Feliu, J. Solid State Electrochem. 15 (2011) 1297-1315.

[12] F.J. Vidal-Iglesias, A. A I-A kl, D. W atson, G.A. A ttard, J. Electroanal. Chem. 611 (2007) $117-125$.

[13] E. Herrero, L.J. Buller, H.D. A bruna, Chem. Rev. 101 (2001) 1897-1930.

[14] S. Szabo, Int. Rev. Phys. Chem. 10 (1991) 207-248.

[15] J. Clavilier, J.M. Feliu, A . A ldaz, J. Electroanal. Chem. 243 (1988) 419-433.

[16] J. Clavilier, J.M. Feliu, A. Fernandezvega, A. A ldaz, J. Electroanal. Chem. 269 (1989) 175-189.

[17] R.W. Evans, G.A . A ttard, J. Electroanal. Chem. 345 (1993) 337-350.

[18] J.M. Feliu, A . Fernández-V ega, A . A ldaz, J. Clavilier, J. Electroanal. Chem. 256 (1988) 149-163.

[19] J.M. Feliu, A. Fernández-V ega, J.M . Orts, A. A ldaz, J. Chim. Phys. Phys.-Chim. Biol. 88 (1991) 1493-1518.

[20] E. Leiva, T. I wasita, E. Herrero, J.M . Feliu, Langmuir 13 (1997) 6287-6293.

[21] M. Shibata, N. Furuya, M. W atanabe, S. M otoo, J. Electroanal. Chem. 263 (1989) 97-108.

[22] E. Herrero, A. Fernández-V ega, J.M. Feliu, A. A Idaz, J. Electroanal. Chem. 350 (1993) 73-88.

[23] M. W atanabe, S. M otoo, J. Electroanal. Chem. 60 (1975) 275-283.

[24] N.M. M arkovic, H.A. Gasteiger, P.N. Ross, X.D. Jiang, I. Villegas, M.J. Weaver, Electrochim. A cta 40 (1995) 91-98.

[25] S.P.E. Smith, K.F. B en-Dor, H.D. A bruna, Langmuir 15 (1999) 7325-7332. 
[26] J.V. Perales-Rondon, A. Ferre-V ilaplana, J.M. Feliu, E. Herrero, J. A m. Chem. Soc. 136 (2014) 13110-13113.

[27] A. B oronat-Gonzalez, E. Herrero, J.M. Feliu, J. Solid State Electrochem. 18 (2014) 1181-1193.

[28] Y .-Y. Y ang, S.-G. Sun, Y .-J. Gu, Z.-Y. Zhou, C.-H. Zhen, Electrochim. A cta 46 (2001) 4339-4348.

[29] F.J. Vidal-Iglesias, J. Solla-Gullón, E. Herrero, A. Aldaz, J.M. Feliu, J. A ppl. Electrochem. 36 (2006) 1207-1214.

[30] X.H. Xia, T. I wasita, J. Electrochem. Soc. 140 (1993) 2559-2565.

[31] H.W. Lei, H. Hattori, H. K ita, Electrochim. A cta 41 (1996) 1619-1628.

[32] A. López-Cudero, F.J. Vidal-Iglesias, J. Solla-Gullón, E. Herrero, A. Aldaz, J.M. Feliu, Phys. Chem. Chem. Phys. 11 (2009) 416-424.

[33] F.J. V idal-Iglesias, A. Lopez-Cudero, J. Solla-Gullon, J.M. Feliu, A ngew. Chem. Int. Ed. 52 (2013) 964-967.

[34] C. B uso-Rogero, J.V. Perales-R ondon, M .J S. Farias, F.J. Vidal-I glesias, J. SollaGullon, E. Herrero, J.M. Feliu, Phys. Chem. Chem. Phys. 16 (2014) 13616-13624.

[35] Q.S. Chen, Z.Y. Zhou, F.J. Vidal-Iglesias, J. Solla-Gullon, J.M. Feliu, S.G. Sun, J. A m. Chem. Soc. 133 (2011) 12930-12933.

[36] M .D. M aciá, E. Herrero, J .M. Feliu, J. Electroanal. Chem. 554 (2003) 25-34.

[37] G.-T. Fu, B.-Y. Xia, R.-G. M a, Y . Chen, Y.-W . Tang, J.-M . Lee, Nano Energy 12 (2015) 824-832.

[38] X. Gao, Y. Li, Q. Zhang, S. Li, Y. Chen, J.-M. Lee, J. M ater. Chem. A 3 (2015) 12000-12004.

[39] M. Gong, F. Li, Z. Y ao, S. Zhang, J. Dong, Y. Chen, Y. Tang, Nanoscale 7 (2015) 4894-4899.

[40] E. Bennett, J. M onzó, J. Humphrey, D. Plana, M. Walker, C. M cConville, D. Fermin, A. Y anson, P. Rodriguez, A CS Catal. 6 (2016) 1533-1539.

[41] Y. K ang, L. Qi, M. Li, R.E. Diaz, D. Su, R.R. A dzic, E. Stach, J. Li, C.B. M urray, ACS Nano 6 (2012) 2818-2825.

[42] E. Casado-Rivera, D.J. V olpe, L. Alden, C. Lind, C. Downie, T. Vázquez-Alvarez, A.C.D. A ngelo, F.J . DiSalvo, H.D. A bruña, J. A m. Chem. Soc. 126 (2004) 4043-4049.

[43] F. M atsumoto, C. Roychowdhury, F.J. DiSalvo, H.D. A bruna, J. Electrochem. Soc. 155 (2008) B 148-B 154.

[44] A. Saéz, C.M. Sánchez-Sánchez, J. Solla-Gullón, E. Expósito, V. M ontiel, J. Electrochem. Soc. 156 (2009) E154-E160.

[45] S. Uhm, S.T. Chung, J. Lee, Electrochem. Commun. 9 (2007) 2027-2031.

[46] C.M. Sánchez-Sánchez, A.J. B ard, A nal. Chem. 81 (2009) 8094-8100.

[47] M. Villanueva-Rodríguez, C.M. Sánchez-Sánchez, V. M ontiel, E. B rillas, J.M. Peralta-Hernández, A . Hernández-R amírez, Electrochim. A cta 64 (2012) 196-204.

[48] C.M. Sanchez-Sanchez, J. Souza-Garcia, A. Saez, V. Montiel, E. Herrero, A. Aldaz, J.M . Feliu, Electrochim. A cta 56 (2011) 10708-10712.

[49] C.M. Sanchez-Sanchez, J. Solla-Gullon, F.J . Vidal-Iglesias, A. A Idaz, V. M ontiel, E. Herrero, J. A m. Chem. Soc. 132 (2010) 5622-5624.

[50] C.M. Sanchez-Sanchez, The Electrochem. Soc. Interface 23 (2014) 43-45.

[51] A.J. Bard, M.V. Mirkin, Scanning Electrochemical Microscopy, in: N.Y. CRC Press, US (Ed.), 2012.

[52] C. J ung, C.M. Sánchez-Sánchez, C.-L. Lin, J. Rodríguez-López, A.J. Bard, A nal. Chem. 81 (2009) 7003-7008.

[53] C.-L. Lin, J. Rodríguez-López, A .J. B ard, A nal. Chem. 81 (2009) 8868-8877.

[54] J . Rodríguez-López, A.J. Bard, J. A m. Chem. Soc. 132 (2010) 5121-5129. 
[55] S. Daniele, S. B ergamin, Electrochem. Commun. 9 (2007) 1388-1393.

[56] F.J. V idal-Iglesias, R.M. A rán-A is, J. Solla-Gullon, E. Herrero, J.M. Feliu, ACS Catal. 2 (2012) 901-910.

[57] J. Solla-Gullón, P. Rodríguez, E. Herrero, A. Aldaz, J.M. Feliu, Phys. Chem. Chem. Phys. 10 (2008) 1359-1373.

[58] J. Solla-Gullón, F.J. Vidal-Iglesias, A. López-Cudero, E. Garnier, J.M. Feliu, A. Aldaz, Phys. Chem. Chem. Phys. 10 (2008) 3689-3698.

[59] J. Solla-Gullon, E. Garnier, J.M. Feliu, M. Leoni, A . Leonardi, P. Scardi, J. A ppl. Crystallogr. 48 (2015) 1534-1542.

[60] C.M. Sánchez-Sánchez, J. Souza-Garcia, E. Herrero, A. Aldaz, J. Electroanal. Chem. 668 (2012) 51-59.

[61] Y. Shao, M .V . M irkin, J. Phys. Chem. B 102 (1998) 9915-9921.

[62] D.A. W alsh, J.L. Fernández, J. M auzeroll, A .J . Bard, A nal. Chem. 77 (2005) 51825188.

[63] 0. Lugaresi, J.V. Perales-R ondon, A . M inguzzi, J. Solla-Gullon, S. Rondinini, J.M. Feliu, C.M. Sanchez-Sanchez, A pplied Catalysis B 163 (2015) 554-563.

[64] F. Zhou, P.R. Unwin, A.J. Bard, The Journal of Physical Chemistry 96 (1992) 4917-4924.

[65] R. A dzic, E. Y eager, B.D. Cahan, J. Electrochem. Soc. 121 (1974) 474-484.

[66] F. ElO mar, R. Durand, J. Electroanal. Chem. 178 (1984) 343-350.

[67] B.N. Grgur, N.M . M arkovi •, P.N. Ross, Langmuir 13 (1997) 6370-6374.

[68] Z.Y. Zhou, N. Tian, Z.Z. Huang, D.J. Chen, S.G. Sun, Faraday Discuss. 140 (2008) 81-92.

[69] M.J. Henderson, E. Bitziou, A.R. Hillman, E. Vieil, J. Electrochem. Soc. 148 (2001) E105-E111.

[70] J. Clavilier, J.M . Orts, J.M . Feliu, A. A ldaz, J. Electroanal. Chem. 293 (1990) 197208.

[71] M.P. M ercer, D. Plana, D.J. Fermn, D. Morgan, N. Vasiljevic, Langmuir 31 (2015) 10904-10912.

[72] M .J. Llorca, E. Herrero, J.M. Feliu, A. A Idaz, J. Electroanal. Chem. 373 (1994) 217-225.

[73] E. Herrero, J.M. Feliu, A . A Idaz, J. Electroanal. Chem. 368 (1994) 101-108.

[74] A. Ferre-Vilaplana, J.V. Perales-Rondon, J.M. Feliu, E. Herrero, ACS Catal. 5 (2015) 645-654.

[75] H. Wang, L. Alden, F.J. DiSalvo, H.D. A bruna, Phys. Chem. Chem. Phys. 10 (2008) 3739-3751. 


\section{Figure captions}

Figure 1. SECM M D/SC images displaying the substrate current collected for $\mathrm{HCOOH}$ oxidation at different potentials in a deaerated $0.5 \mathrm{M} \mathrm{H}_{2} \mathrm{SO}_{4}$ solution at pristine and $\mathrm{Pb}$ modified $\left(\theta_{\max }\right)$ Pt UME (diameter $\left.=100 \mu \mathrm{m}\right)$. The micropipette tip scan rate was 75 $\mu \mathrm{m} . \mathrm{s}^{-1}$ and the micropipette-substrate el ectrode distance was $50 \mu \mathrm{m}$. M icropipette filled with 50:50 (v/v) DCE:HCOOH.

Figure 2. TEM pictures for (A) octahedral, (B) cubic and (C) quasi-spherical Pt NPS.

Figure 3. (a) Voltammetric profiles in argon saturated $0.5 \mathrm{M} \mathrm{H}_{2} \mathrm{SO}_{4}$ solution for $\mathrm{Pb}$ modified A u substrate electrode (black plot); $\mathrm{Pb}_{\theta} / 111$-Pt NPs on A u substrate (red plot) and $\mathrm{Pb}_{\theta} / 111$-Pt NPs on GC substrate (blue plot) at maximum coverage $\left(\theta_{\mathrm{Pb}}\right)$ in all three cases. (b) Voltammetric profile in argon saturated $0.1 \mathrm{M} \mathrm{HCOOH}$ and $0.5 \mathrm{M} \mathrm{H}_{2} \mathrm{SO}_{4}$ solution on gold pristine disk electrode (black plot) and on $\mathrm{Pb}$ modified gold disk electrode (red plot). Scan rate: $0.05 \mathrm{~V} \mathrm{~s}^{-1}$.

Figure 4. V oltammetric profiles: (a) $\mathrm{Pb}_{\theta} /$ poly-Pt NPs, b) $\mathrm{Pb}_{\theta} / 100$-Pt NPs and c) $\mathrm{Pb}_{\theta}$ /111-Pt N Ps with different Pb coverage $\left(\theta_{\mathrm{Pb}}\right)$. Scan rate: $0.05 \mathrm{~V} . \mathrm{s}^{-1}$. Test solution: argon saturated $0.5 \mathrm{M} \mathrm{H}_{2} \mathrm{SO}_{4}$.

Figure 5. Voltammetric profiles: (a) $\mathrm{Pb}_{\theta} / 100-\mathrm{Pt} \mathrm{NPs}$ and b) $\mathrm{Pb}_{\theta} / 111-\mathrm{Pt} \mathrm{NPs}$ at low $\left(\theta_{\mathrm{Pb}} / 100-\mathrm{Pt}=0.27\right.$ and $\left.\theta_{\mathrm{Pb}} / 111-\mathrm{Pt}=0.31\right)$ (black plots) and at maximum $\mathrm{Pb}$ coverage $\left(\theta_{\max }\right)$ (red plots). Solid plots represent CV s before FAOR experiments, whereas dash 
dotted plots represent CV s after FA OR experiments. Scan rate: $0.05 \mathrm{~V} . \mathrm{s}^{-1}$. Test solution: argon saturated $0.5 \mathrm{M} \mathrm{H}_{2} \mathrm{SO}_{4}$.

Figure 6. Voltammetric profiles for FAOR. Solid line, positive scan direction and dashed line, negative scan direction. (a) $\mathrm{Pb}_{\theta}$ /poly-Pt NPs, b) $\mathrm{Pb}_{\theta} / 100-\mathrm{Pt} \mathrm{NPs}$ and c) $\mathrm{Pb}_{\theta} / 111-\mathrm{Pt} N \mathrm{Ps}$ with different $\mathrm{Pb}$ coverages $\left(\theta_{\mathrm{Pb}}\right)$. Scan rate: $0.02 \mathrm{~V} . \mathrm{s}^{-1}$. Test solution: argon saturated $0.1 \mathrm{M} \mathrm{HCOOH}$ in $0.5 \mathrm{M} \mathrm{H}_{2} \mathrm{SO}_{4}$.

Figure 7. Catalytic activity comparison between the three types of pristine and $\mathrm{Pb}$ modified $\left(\theta_{\max }\right)$ shape-controlled Pt N Ps by calculating the catalytic enhancement ratio from the corresponding current densities displayed in Figure $6 . \mathrm{Pb}_{\theta} /$ poly-Pt N Ps, black solid plot; $\mathrm{Pb}_{\theta} / 100-\mathrm{Pt} \mathrm{N}$ s, red solid plot and $\mathrm{Pb}_{\theta} / 111-\mathrm{Pt} \mathrm{NPs}$, green solid plot.

Figure 8. Chronoamperometric curves recorded at $0.3 \mathrm{~V}$ VS RHE for catalytic evaluation of FAOR. (a) $\mathrm{Pb}_{\theta} /$ poly-Pt NPs, b) $\mathrm{Pb}_{\theta} / 100-\mathrm{Pt} N \mathrm{Ps}$ and c) $\mathrm{Pb}_{\theta} / 111-\mathrm{Pt} \mathrm{NPs}$ with different $\mathrm{Pb}$ coverages $\left(\theta_{\mathrm{Pb}}\right)$. Test solution: argon saturated $0.1 \mathrm{M} \mathrm{HCOOH}$ in 0.5 $\mathrm{M} \mathrm{H}_{2} \mathrm{SO}_{4}$.

Figure 9. Chronoamperometric curves recorded at $0.5 \mathrm{~V}$ VS RHE for catalytic evaluation of FAOR. (a) $\mathrm{Pb}_{\theta} /$ poly-Pt NPs, b) $\mathrm{Pb}_{\theta} / 100-\mathrm{Pt} N \mathrm{Ps}$ and c) $\mathrm{Pb}_{\theta} / 111-\mathrm{Pt} N \mathrm{Ps}$ with different $\mathrm{Pb}$ coverages $\left(\theta_{\mathrm{Pb}}\right)$. Test solution: argon saturated $0.1 \mathrm{M} \mathrm{HCOOH}$ in 0.5 $\mathrm{M} \mathrm{H}_{2} \mathrm{SO}_{4}$. 
Table 1. Current collected on the SECM images and catalytic enhancement factor comparing those currents for Pt and Pb-Pt electrodes at 0.3 and $0.5 \mathrm{~V}$.

\begin{tabular}{cccc}
\hline $\begin{array}{c}\text { Applied } \\
\text { potential (V) }\end{array}$ & $\begin{array}{c}\mathrm{I}_{\text {collected }}(\mathrm{nA}) \\
\mathbf{P t}\end{array}$ & $\begin{array}{c}\mathrm{I}_{\text {collected }}(\mathrm{nA}) \\
\mathbf{P b}-\mathbf{P t}\end{array}$ & $\begin{array}{c}\text { Catalytic } \\
\text { enhancement factor }\end{array}$ \\
\hline $\mathbf{0 . 3}$ & 1.1 & 14.3 & 13 \\
$\mathbf{0 . 5}$ & 8.7 & 34.8 & 4 \\
\hline
\end{tabular}

Table 2. Density current at 0.3 and $0.5 \mathrm{~V}$ from the positive-sweep voltammetric profile performed at $0.02 \mathrm{~V} \mathrm{~s}^{-1}$ in $0.1 \mathrm{M} \mathrm{HCOOH}$ and $0.5 \mathrm{M} \mathrm{H}_{2} \mathrm{SO}_{4}$ solution for each type of shape controlled Pt NPs modified at maximum coverage by $\mathrm{Pb}$ and $\mathrm{TI}$ and at optimum coverage by Sb. Their corresponding catalytic enhancement factors are also included. They are all calculated in comparison with the current densities on pristine Pt N Ps reported here.

\begin{tabular}{|c|c|c|c|c|}
\hline & $\begin{array}{c}\mathrm{j} \text { at }(0.3 \mathrm{~V}) \\
/ \mu \mathrm{A} \mathrm{cm}\end{array}$ & $\begin{array}{c}\text { Catalytic } \\
\text { enhancement } \\
\text { factor at } 0.3 \mathrm{~V}\end{array}$ & $\begin{array}{c}\text { j at }(0.5 \mathrm{~V}) / \\
\mu \mathrm{A} \mathrm{cm}\end{array}$ & $\begin{array}{c}\text { Catalytic } \\
\text { enhancement } \\
\text { factor at } 0.5 \mathrm{~V}\end{array}$ \\
\hline poly-Pt NPs & 46.6 & & 341 & \\
\hline 100-Pt NPs & 32.7 & & 210 & \\
\hline 111-Pt NPs & 41.7 & & 372 & \\
\hline $\mathrm{Pb}_{\theta} /$ poly-Pt NPs & 628 & 13.5 & 2975 & 8.7 \\
\hline $\mathbf{P b}_{\theta} / 100-P t$ NPs & 553 & 16.9 & 3770 & 18 \\
\hline $\mathrm{Pb}_{\theta} / 111-\mathrm{Pt}$ NPs & 642 & 15.4 & 6718 & 18 \\
\hline${ }^{\mathrm{a}} \mathrm{Sb}_{\theta} /$ poly-Pt NPs & 520 & 9 & 2150 & 6.3 \\
\hline${ }^{\mathrm{a}} \mathrm{Sb}_{\theta} / \mathbf{1 0 0}-\mathrm{Pt} \mathrm{NPs}$ & 260 & 8 & 1070 & 5.1 \\
\hline${ }^{\mathrm{a}} \mathrm{Sb}_{\theta} / \mathbf{1 1 1 - P t} \mathbf{N P s}$ & 820 & 19.7 & 2880 & 7.7 \\
\hline${ }^{\mathrm{b}} \mathrm{TI}_{\theta} / 100-\mathrm{Pt} \mathrm{NPs}$ & 712 & 21.8 & 2447 & 11.7 \\
\hline${ }^{\mathrm{b}} \mathrm{TI}_{\theta} / 111-P t$ NPs & 425 & 10.2 & 1670 & 4.5 \\
\hline
\end{tabular}

${ }^{a}$ From reference [33]

${ }^{b}$ From reference [34] 
Table 3. Chronoamperometric activities at $600 \mathrm{~s}$ and deactivation percentage at 0.3 and $0.5 \mathrm{~V}$ for each shape controlled Pt NPs modified by Pb calculated by comparing the current density in the corresponding chronoamperometry at $60 \mathrm{~s}$ and $600 \mathrm{~s}$.

\begin{tabular}{|c|c|c|c|c|}
\hline & $\begin{array}{c}\text { j a } 600 \mathrm{~s}(0.3 \mathrm{~V}) \\
/ \mu \mathrm{A} \mathrm{cm}\end{array}$ & $\begin{array}{c}\mathrm{j} \text { a } 600 \mathrm{~s}(0.5 \mathrm{~V}) / \\
\mu \mathrm{A} \mathrm{cm}\end{array}$ & $\begin{array}{l}\text { Deactivation } \\
\text { at } 0.3 \mathrm{~V}(\%)\end{array}$ & $\begin{array}{l}\text { Deactivation } \\
\text { at } 0.5 \mathrm{~V}(\%)\end{array}$ \\
\hline $\mathrm{Pb}_{\theta} /$ poly-Pt NPs & 380 & 2530 & 20 & 10 \\
\hline $\mathrm{Pb}_{\theta} / 100-\mathrm{Pt}$ NPs & 340 & 2250 & 20 & 17 \\
\hline $\mathrm{Pb}_{\theta} / 111-\mathrm{Pt}$ NPs & 350 & 4190 & 27 & 15 \\
\hline
\end{tabular}




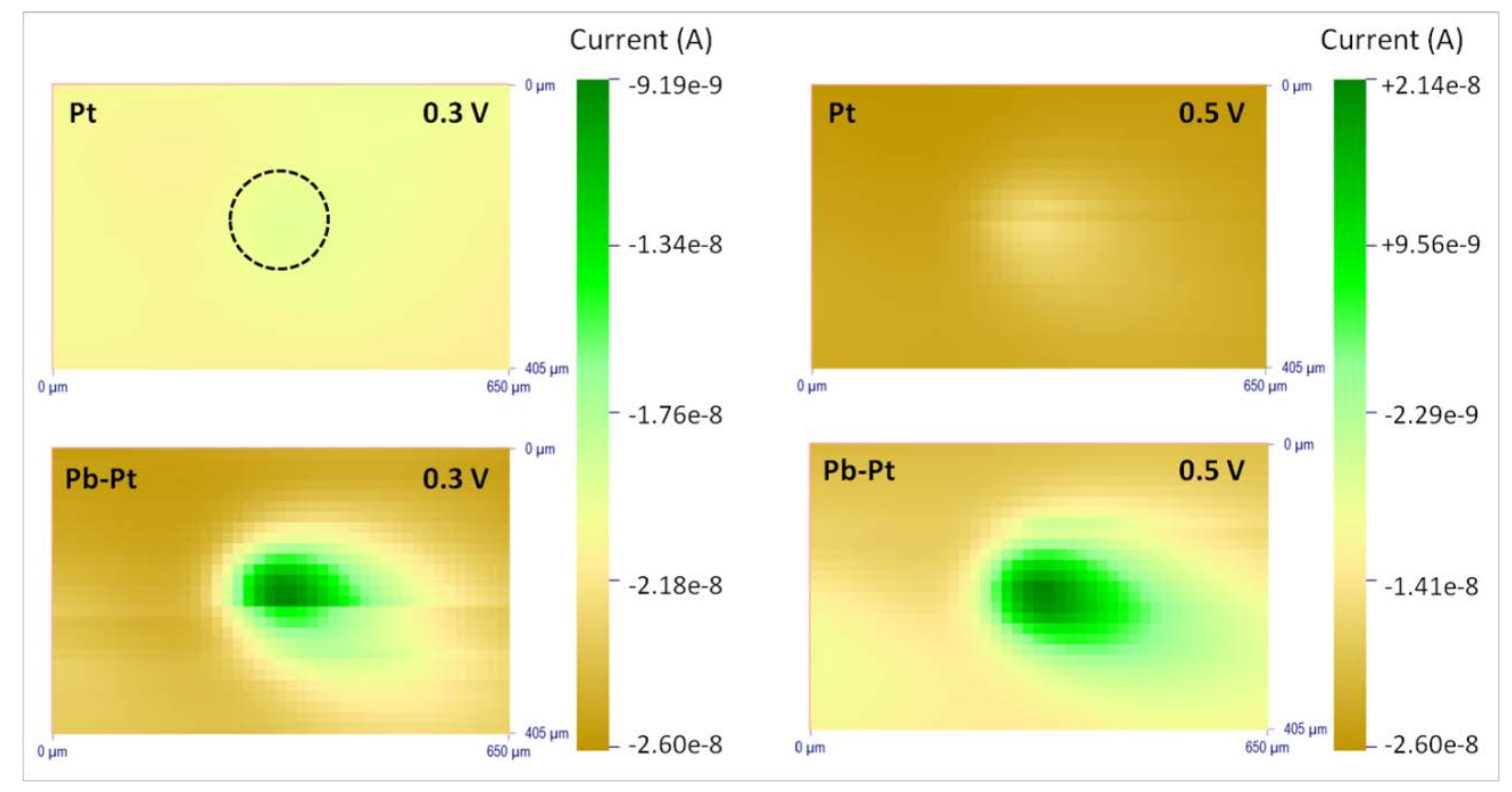

Figure 1. 

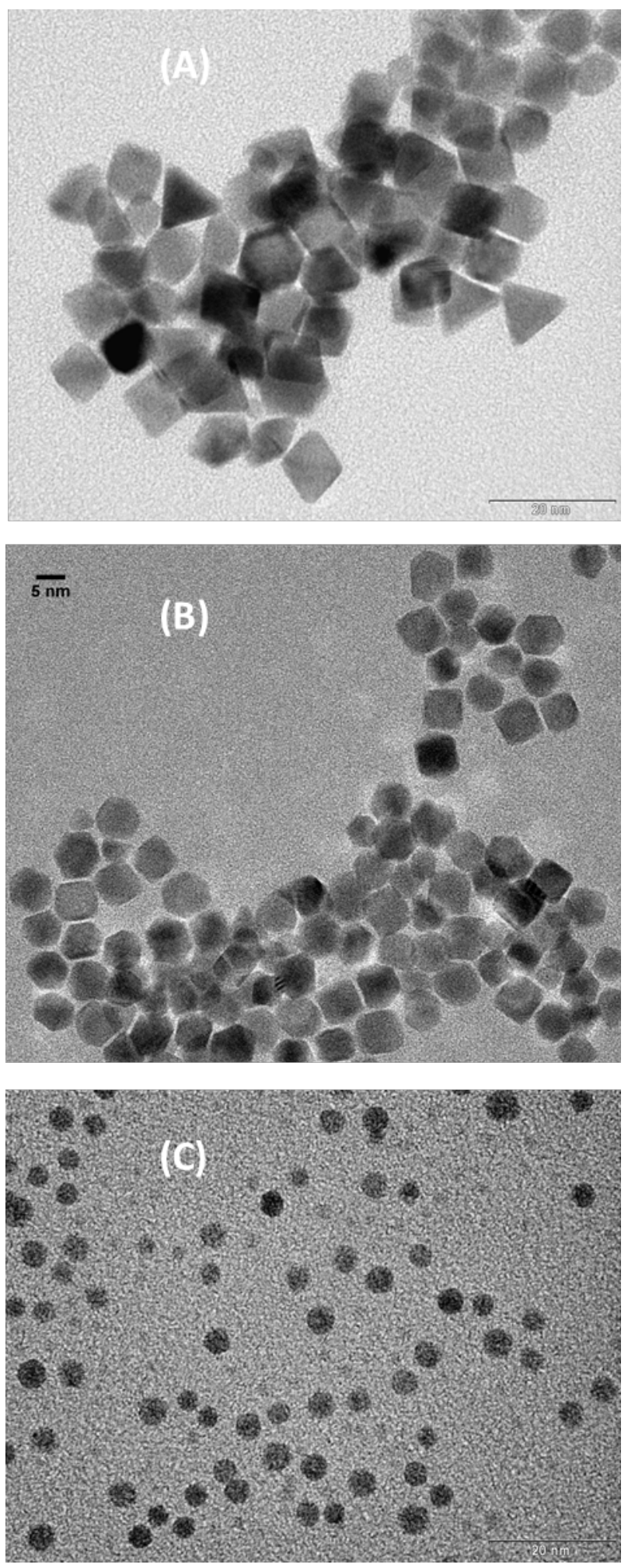

Figure 2. 


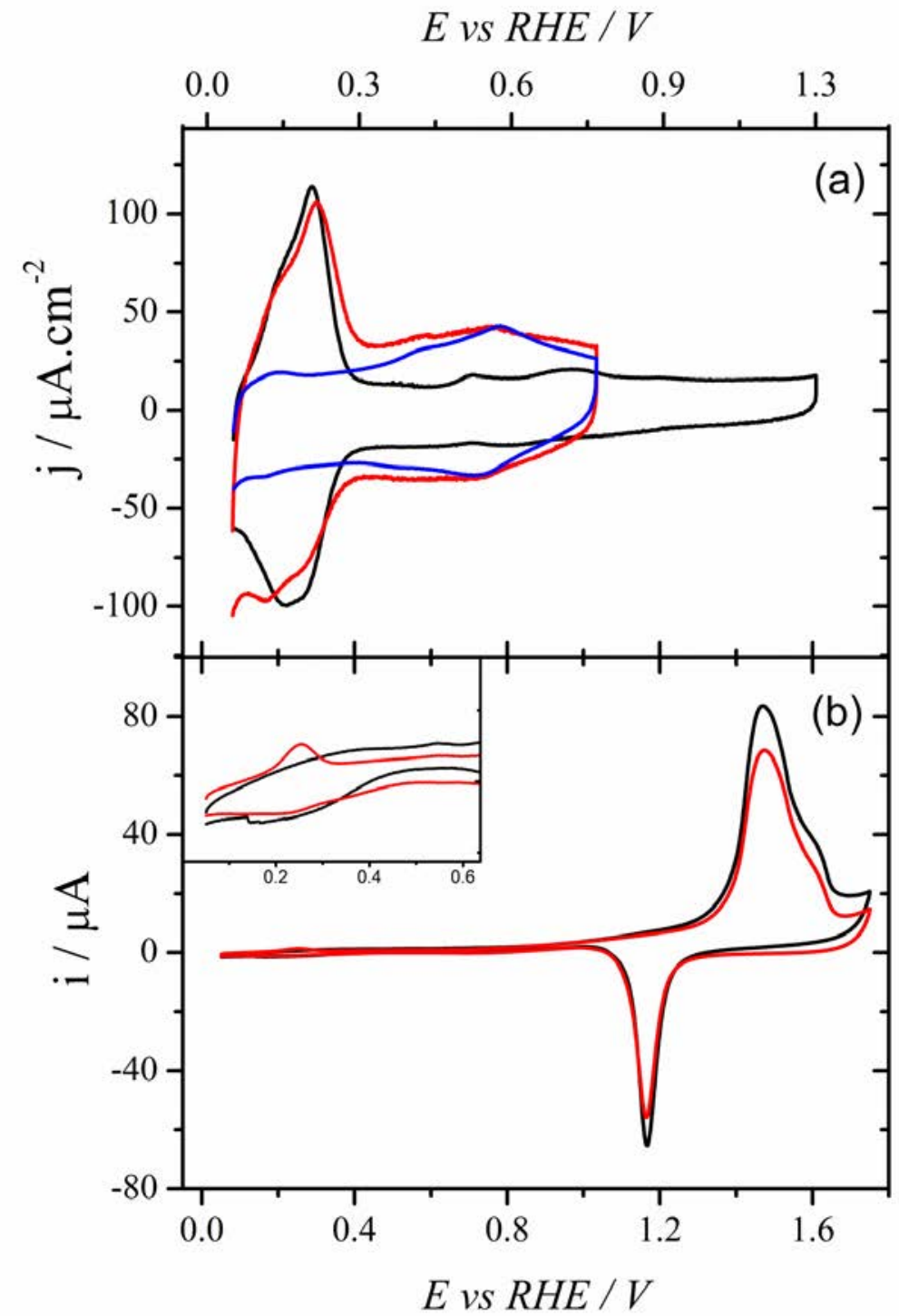

Figure 3. 


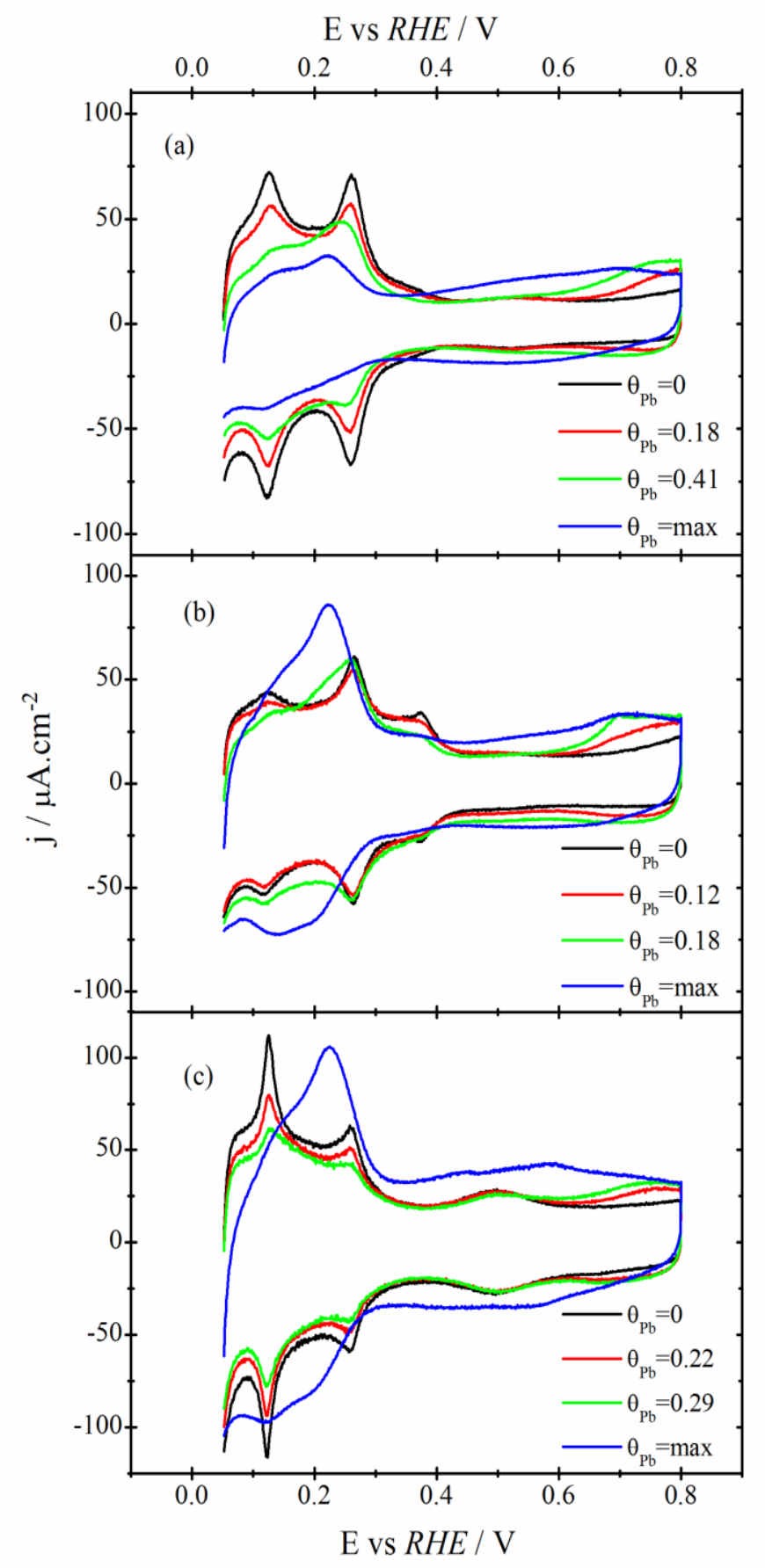

Figure 4. 


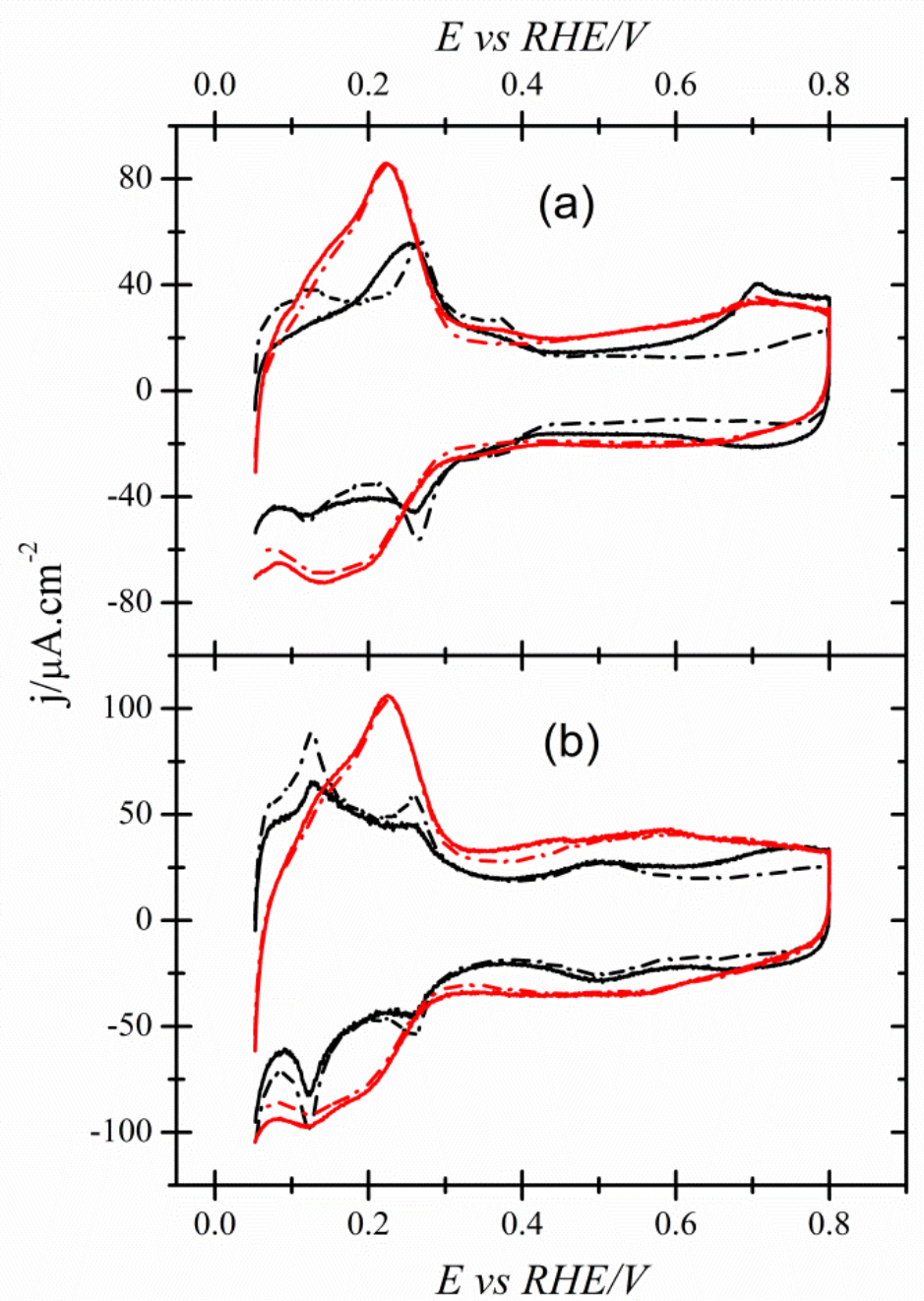

Figure 5. 


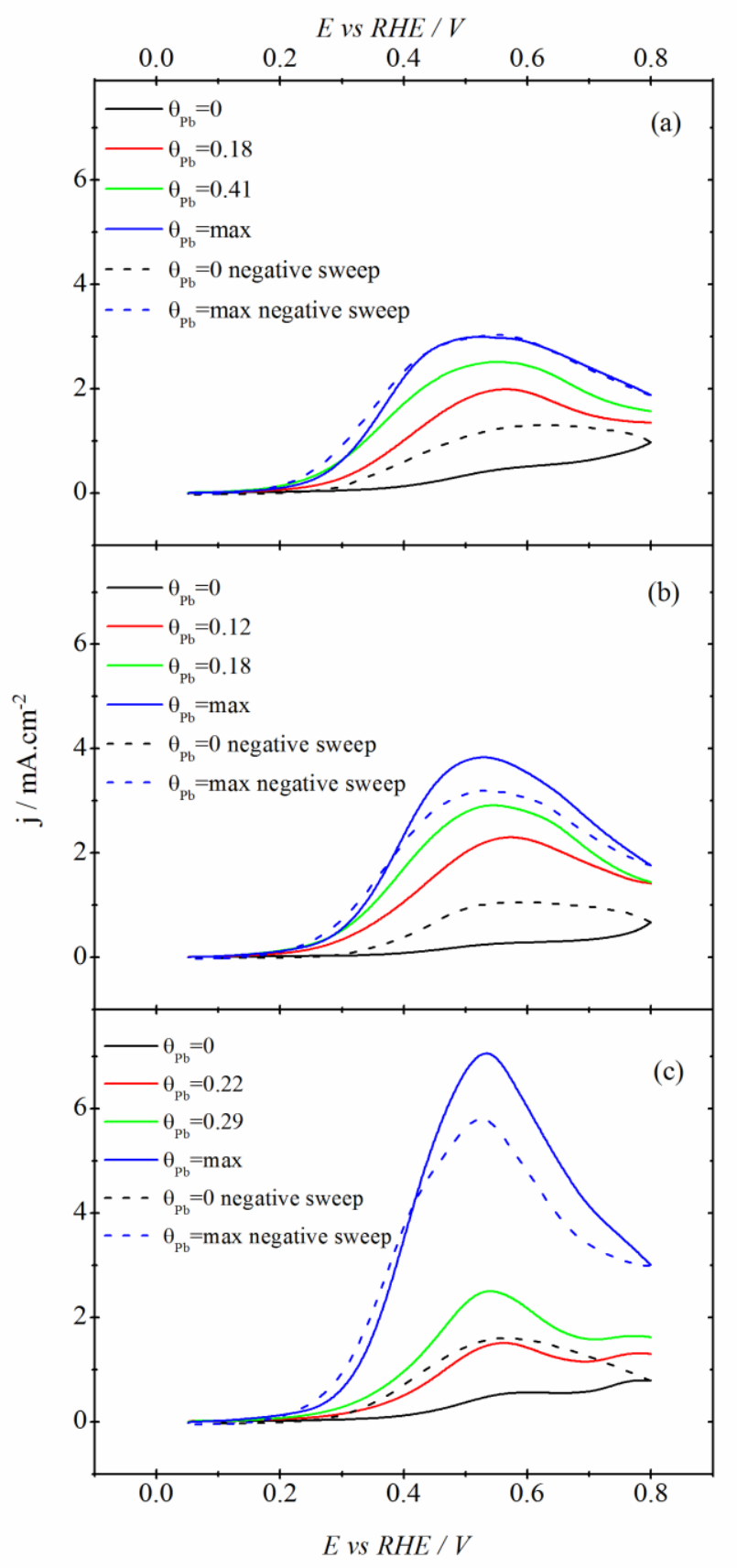

Figure 6. 


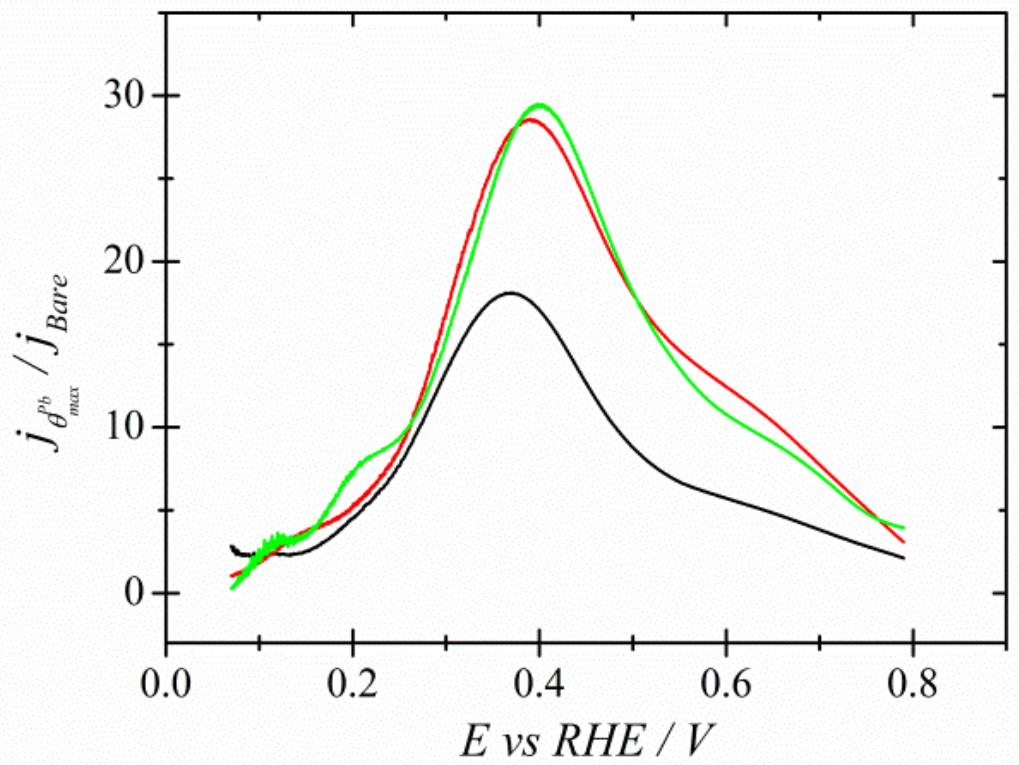

Figure 7. 


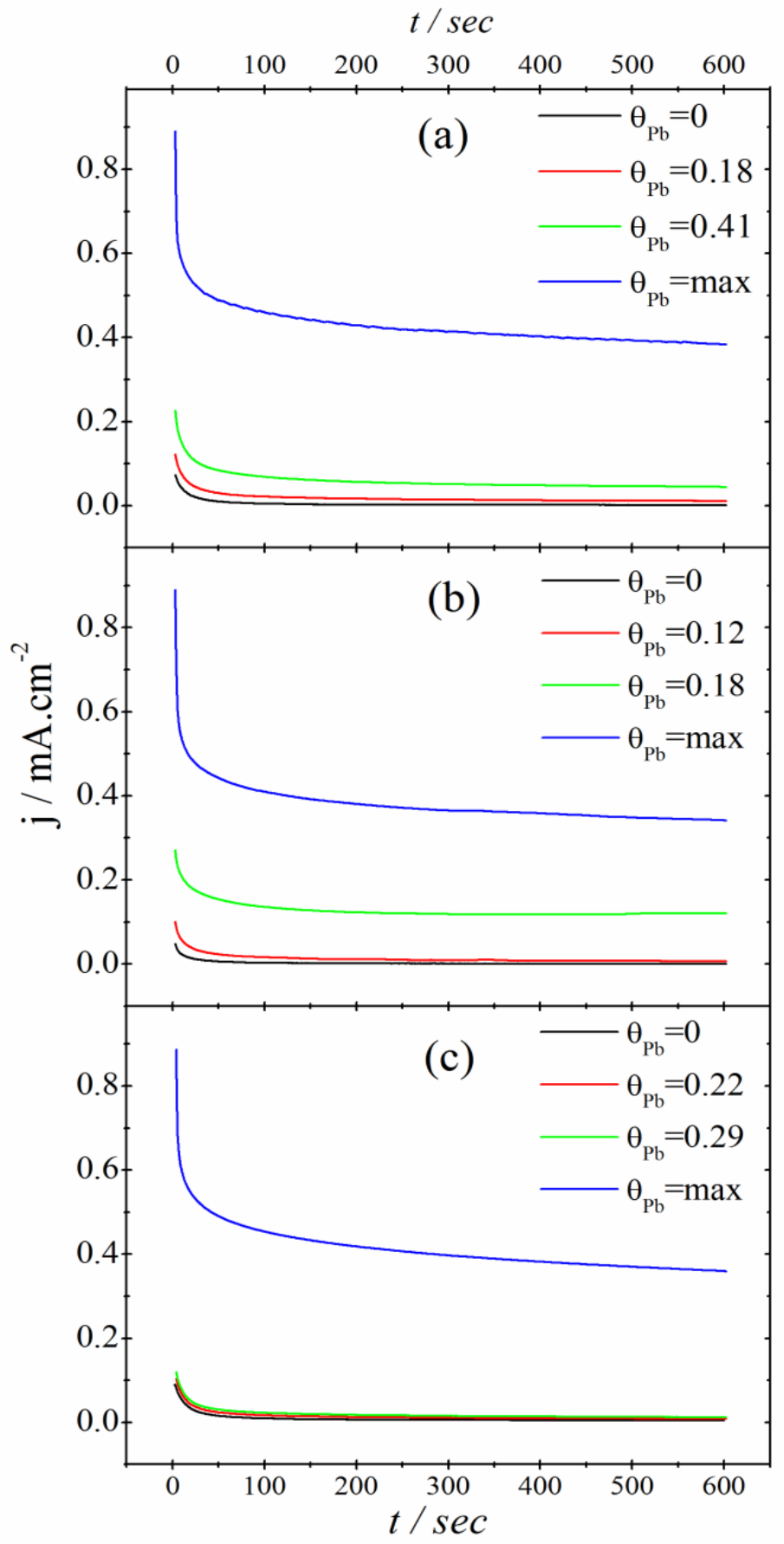

Figure 8. 


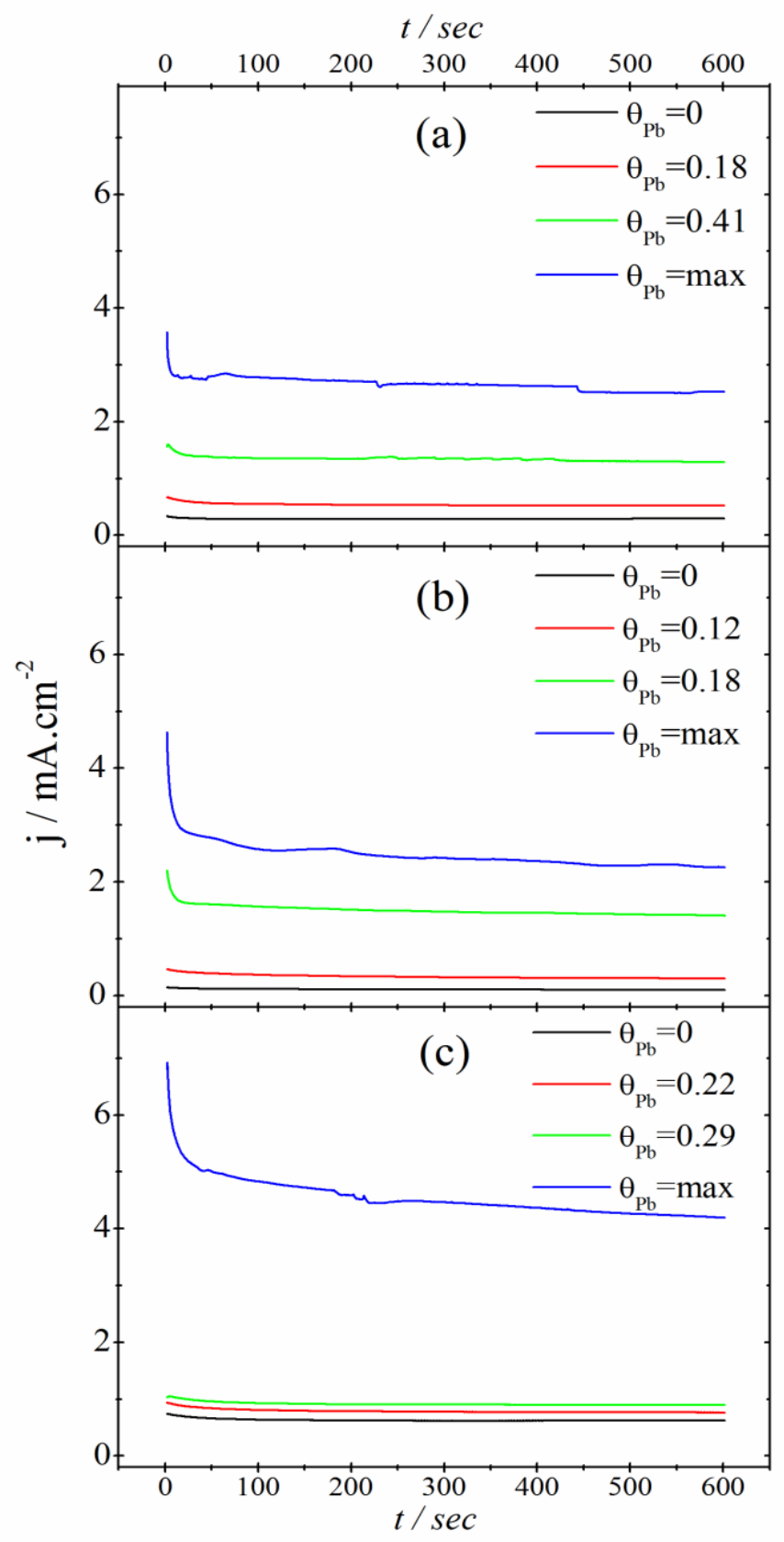

Figure 9. 